\title{
Dubai's Museum Types: A Structural Analytic
}

John Biln and Mohamed El-Amrousi

This is a pre-print version of the following article, published in print form and available online: http:/www.ingentaconnect.com/content/berghahn/armw/2014/00000002/00000001/art00007. Biln, John, and Mohamed El-Amrousi. "Dubai's Museum Types: A Structural Analytic." Museum Worlds: Advances in Research 2 (2014): 99-112.

\begin{abstract}
Dubai is often characterized as a city of artificiality and repackaged public spaces - a city without a past. The old historic Dubai has essentially disappeared, lost in the shadows of iconic resort projects and popular shopping malls. This article asks the following question: how do Dubai's museums function in relation to an urban field for the most part bereft of historical fabric, and in which the history that is made visible within the public realm is largely fictional or highly sanitized? We argue that to make sense of the ways history is represented and circulated in Dubai's public spaces, the traditional categories of 'museum' should be extended to include both large-scale history-themed malls and small heritage houses. Taken altogether, Dubai's museums and museum-like institutions constitute a conceptually complete and closed system that manages to 'resolve' the apparent paradox of an urban context characterized by absence and historical loss, in which, paradoxically, expressions of historical fullness are everywhere.
\end{abstract}

The rapid urban development and commercial repackaging of public space in Dubai has resulted in a city of overwhelming artificiality. Iconic projects such as the Palm Island, Burj al-Arab, Burj Dubai (now Burj Khalifa) have collectively given a compelling image to Dubai's global pretensions. At the same time, however, they have accomplished this without any substantial engagement of Dubai's specific cultural heritage (Steiner 2010). Lacking a strongly preconceived historical image, Dubai has constructed the façade of a contemporary global city in what its planners determined was essentially an historical vacuum (Acuto 2010). In an apparent effort to redress this loss of history, exclusive and lavish themed hotels and high-end resorts such as AlJumeirah's Palace Hotel and the Miraj Hotel, dominant in any mental map of the city, express a sense of the city as some sort of fusion of tradition and modernity. These resort spaces and theme malls, however, offer little more than man-made waterways, mimicked abra boat rides and an architectural scenography incorporating superficial references to a wider Arab history. These altogether give very weak reference to Dubai's actual historical environments such as those along Dubai Creek in Diera. By a strategy of simulation and authentication, even extant historic zones are essentially reframed as bounded places available for the brief tastes of 'reality' that ultimately serve to validate, rather than to challenge, the simulated and sanitized environments offered by Dubai's hotels and malls. It is thus unsurprising that Dubai appears in the literature as an instant city, a city of spectacle, a city built on shifting sands, a city of a very particular present - a city without a past (Davis 2007; Bagaeen 2007; Kanna 2005). In general, Dubai has come to appear either as a city with no debts to its past, or as a city in which any historical references immediately return to a set of artificial renderings of that history. While Dubai is, of course, 
necessarily more than this, it is true that such critiques capture something of the character of the place.

Having said that, Dubai is obviously the product of historical development, which includes several centuries of pearling and trade settlement going back far beyond the $19^{\text {th }}$-century residential fabric stretching from the Diera waterfront inland along the Dubai Creek (Khor Dubai). These areas contain the last substantially visible fragments of built heritage in the city. Even these areas clustered around the creek, however, represent only a tiny proportion of the built fabric of the city, and have been almost entirely eclipsed by the megamalls, theme resorts and artificial residential islands that have come to symbolize Dubai. It is these newer developments, many incorporating explicitly 'historical' iconographies, which have become the dominant material vehicles for expressing the past. The history they project has little to do with the actual history of the place, however, and tends instead to consumable narratives drawn from an archive of images and forms from around and beyond the wider Arab world.

This article asks the following question: how do Dubai's museums function in relation to an urban field for the most part bereft of historical fabric, and in which the history that is made visible within the public realm is largely fictional or, at the very least, highly sanitized? The approach taken here has been to study the public expression, rather than backroom activities or internal strategies, of important museums in the city. Observations were made on a number of occasions between 2010 and 2012, with an emphasis on what a visitor might see of a museum in a typical visit to the institution or when traversing the city. With the exception of Ibn Battuta, a theme mall that we will consider to be 'museum-like' and located in the extreme southwest of the city, all the institutions visited are located in areas adjacent or near the historic Dubai Creek in the northeast of the city. Most of Dubai's museums are located in this area. Our interest has been to get a sense of how these institutions present history in the context of city experience as a whole, much of it dominated, in an image-oriented city such as Dubai, by visual signals; as well as how these institutions construct history in the context of historical narratives presented or depicted more informally in the city. We make the assumption that any sense of a city's history given in urban experience is given by exposure both to institutions with explicit historical mandates, such as museums, and to institutions with far more informal approaches to the past, such as malls and themed resorts, which tend to appropriate historical images principally for commercial or aesthetic reasons. Beyond this, we assume that any sense of history present in a city such as Dubai will necessarily be grasped against a context richly populated by images and rhetorics of modernity or progress but in which fragments of historic urban fabric still persist. The interpretive infrastructure we use is broadly semiological, an approach we believe is consonant with an analysis that privileges structural interests, visible forms of evidence, and, ultimately, potentials for conscious or unconscious impacts on a receiving public. We are much less concerned with intentions and agendas, that is, than with symptoms of structural organization and their potential for collective conceptual effect.

This article considers the various types of museums present in Dubai, and argues that to make sense of the ways history is represented and circulated in Dubai's public institutions, the category of 'museum' should be extended to include large-scale history-themed malls, on the one hand, and small heritage houses, on the other. We will see not only that these two institutional types are structurally related to more traditional museums in Dubai, but that altogether Dubai's museums and museum-like institutions constitute a conceptually complete and closed system that manages 
to 'resolve' the paradox of a context characterized by absence and historical loss, but in which expressions of historical fullness are everywhere.

Before considering Dubai itself, however, we will find it useful to revisit the essential museological conditions of object display and interpretation insofar as these underwrite the history museum's fundamental operations and claims to legitimacy.

\section{MUSEOLOGY AND INSTITUTIONAL TYPE}

In her classic essay 'Objects of Ethnography', Barbara Kirshenblatt-Gimblett outlines the fundamental conceptual opposition characterizing institutional museology: the dichotomy of approach she labels in situ and in context, the first in which the boundaries of the displayed object are expanded 'to include more of what was left behind, even in replica, after the object was excised from its physical, social, and cultural settings'; and the second in which an isolated object is 'framed' by 'particular techniques of arrangement and explanation to convey ideas' using labels, charts, diagrams, commentaries and narratives of various kinds (Kirshenblatt-Gimblett 1991). Essentially, in situ approaches attempt to preserve a sense of linkage between object and the environment, broadly understood, in which it was originally embedded, while in context approaches effectively isolate an object in order to place it into interpretive or explanatory, rather than environmental, contexts. As Kirshenblatt-Gimblett notes early in her essay, this emphasis on the physical object is a genealogical artifact of the museum's origin in the 'cabinet of curiosities', constructions which have understandably tended to invest the 'fragment' with special importance. In a very real sense, museology has its deep roots in a consuming interest in an object as such. This object centrality was later coupled with a belief that some sense of physical or interpretive context could and should be meaningfully provided.

Although Kirshenblatt-Gimblett is primarily concerned with the vicissitudes of a subject group's depiction as produced through the positioning and rendering of artifacts, her identification of the duality in-situ/in-context can be understood more generally as a core logic underwriting the historico-museological enterprise in toto. In its simplest form, the in-situ approach is most clearly represented by the heritage village (where the embedment of objects in original sites and environments provides meaning), while the in-context strategy captures the essential logic of the classic museum (where explanation and interpretation provides a sense of meaning for the objects displayed). We are speaking here of two broad logics of object explication, of course, recognizing that specific museums may incorporate elements of both approaches. Nonetheless, the two approaches remain conceptually distinct, and one or the other tends to dominate depending on the intentions and typology of the institution in question.

\section{MUSEUM TYPOLOGY IN DUBAI}

In-situ and in-context museological approaches are clearly evident in, respectively, Dubai Heritage Village and in the purpose-built 'classic' museums similar to the Louvre or the Guggenheim projects down the coast in Abu Dhabi. Specific examples of this classic type are not yet evident in Dubai proper, but as Hooper-Greenhill and countless others have pointed out, this type, most obviously in the example of the British Museum, represents the founding conceit of the history museum (Hooper-Greenhill 2000; Watenpaugh 2004; Shaw 2003). Indeed, despite 
Kirshenblatt-Gimblett's quite reasonable tendency to dichotomize in-situ and in-context approaches, suggesting something like equal weight, the classic museum and its in-context approach remains the fundamental model for all subsequent variations, including the heritage village.

\section{a) Classic Museum Typology}

Although the museum has a long history, the British Museum has in many ways set the standard for the museum as an institutional type. Indeed, Julian Spalding goes so far as to call the British museum 'the mother of all modern museums' (Spalding 2006). Museums of this type tend to assume an authoritative position, maintaining a largely 'one-way' form communication in which the meanings of objects and collections are dominated by a singular and paternal interpretive voice (Anderson 2004). The British Museum exemplifies the museum archetype in physical form, a classical stone building 'replicating ancient Greek Temples, with crowds lined up to enter this sanctified repository of cultural representations' (Hooper-Greenhill 2000). Such museums are characterized by a monumental expression that solidifies a sense of power and legitimacy though scale and symbolism, and, accordingly, tend to bolster the credibility of the interpretive strategies employed to 'position' artifacts in their collections. Typical of this classic museological model is the in-context explanatory approach, which can take several forms. Michael Baxandall notes that this approach includes a range of strategies by which 'objects are presented in vitrines, on stands, or on walls and are accompanied by labels, leaflets, or a catalogue' (Baxandall 1991). He goes on to note that 'context' may be further enhanced through the use of video, film, music or dramatic performance. Ultimately, the classic museum focuses on an array of objects and artifacts offered for inspection under a regime of explanatory materials largely controlled by curatorial fiat. The Abu Dhabi Louvre, Shaikh Zayed Museum and the Guggenheim, all designed by internationally renowned architects, are currently under construction in UAE. These institutions, and the museums that inspired them, are obvious examples of mega museums that follow the core logic of the classic museum type. It is only a matter of time before Dubai itself lays the foundation stone for a similar museum in this grand classical mode. Regardless, an ongoing and perhaps even defining sense of competition and tension between Abu Dhabi and Dubai renders Abu Dhabi's high profile museums of this type inescapably 'present' in Dubai. Built or un-built, it is under the dominance of this museological approach that all museum variations present in Dubai, including examples that follow the heritage village model, can be understood as to operate.

\section{b) Heritage Village}

Kirshenblatt-Gimblett notes that in-situ approaches typically take the form of 'environmental and recreational displays' in which artifacts are integrated into installations that effectively rely on physical embedment to 'explain' the social and cultural contexts of the artifacts presented. This approach, which is at once typical of the heritage village model and intrinsic to its operation, can be understood as an antidote to the classic museum and its rather forbidding museological authority.

A brief reminder of the developmental history of the type may be in order here. The roots of the heritage village can be found in the establishment of the $19^{\text {th }}$-century open air museums, in which mock villages of ethnographic subjects considered 'different' were constructed for the edification and entertainment of citizens of colonizing nations. In practice, this meant gathering of items 
considered characteristic and representative of a particular culture, and often peopling the villages with performers from distant locales or different sections of the community (Coombes 1998). History environments such as the outdoor museum and the period room represented a reaction against the traditional museum's strategy of presenting historical environments through casts and fragments of architectural decoration. And, like the earlier ethnic villages, these heritage villages offered a wide array of 'living' demonstration, involving, for example, costumed docents, live craft work, and the preparation of traditional foods. They focused on placing and activating in a physical context past expressions and ways of life, one effect of which is the encouragement of anecdotal rather than systematic interpretation. The way of life supposedly retained and simply presented in open air museums, largely comprised of inherited craft techniques and products, was essentially that of a highly idealized preindustrial culture (Kaufmann 2004). This attempt to retrieve vanishing traditions was ultimately fueled by an acute sense of loss and a deepening nostalgia for a vanishing past. This is the ideology promoted at the fairs and institutionalized at Henry Ford's own outdoor museum of 1927, now known as Greenfield Village, but originally called The Early American Village (Kaufmann 2004).

The Dubai Heritage Village, located at the end of the waterfront promenade of al-Shindagha at the mouth of Dubai Creek, and the Dubai National Museum, located on the old Al-Fahidi fort site nearby on the southwest side of the creek, are each direct descendants of earlier open air history villages. These institutions are located in historic parts of Dubai closely associated with the founding and development of the city. Unsurprisingly, these institutions emphasize the two defining moments in the history of Dubai. The first is the early $19^{\text {th }}$-century when Sheikh Maktoum brought a large contingent of the Bani Yas tribe from eastern Saudi Arabia to settle in Dubai (in al-Shingagha), thus inaugurating a ruling dynasty that continues to this day. The second is the early 1970s, which mark the end of the British protectorate system (established and consolidated around the time of Sheikh Maktoum's settlement), the birth of the United Arab Emirates as an independent political entity, and the rapid growth and prosperity that accompanied the development of Dubai's oil reserves. These two periods of time, and the events that took place during them, continue to serve as the keystones of the local identity that Dubai has striven to preserve in the face of cultural, political and economic competition from Abu Dhabi and elsewhere in the region, as well as to strengthen as a bulwark against the pervasive influence of the 'modern' West.

The museum infrastructure of Dubai, including the heritage villages, can be viewed in part as a by-product of Dubai's development over the forty years since independence. Dubai's museological enterprise can be understood as a response to the uncertainty and change that has accompanied the most recent wave of economic development, in particular, which has brought with it high levels of expatriate immigration, the almost instantaneous emergence of a polyglot socius, and the importation of unfamiliar and sometimes deeply unsettling cultural norms, values and behaviors, as well as the loss of almost all of the informal built fabric that characterized the city well into the 1970s. It has of course also brought tremendous wealth, global visibility and unprecedented urban development. While it would be hard to deny the role of Dubai's museums in attempting something of a rear-guard battle to preserve local identity, or at least mediate the effects of outside influences, the growth of Dubai museums also reflects a recognition that the development of important cultural amenities and public institutions, particularly the more secular variety, were often neglected in the early post-petroleum era. In Dubai, the heritage village has 
proven a popular and tangible, if at times highly 'partial' expression of this sense of civic and cultural responsibility.

Located in historic Bur Dubai on the southwest side of Dubai, Dubai's National Museum, is the most popular and most visited museum in the UAE. The museum relies substantially on cultural backdrops and dioramas to focus attention on the culture of the UAE, specifically Arab bedouins, while excluding other communities (Indian, Persian, African, immigrant Arab) that have coexisted with local Arabs for centuries. The old Al-Fahidi Fort, a fortified residence and therefore by itself something of a house museum, functions within the National Museum complex as an introductory space to a newly constructed underground museum closely akin to the heritage village type. The fort itself has been extensively renovated throughout. The narrow rooms and courtyard of the fort have been transformed to resemble an environment typical of the time prior to the oil boom of the 1970s, and display miniature reed wind towers (barjeel) and palm front kiosks (areesh), as well as accommodating personal tourist services where hand applied henna designs are offered to visitors. The comfortably air-conditioned underground section of the museum guides the visitor through a contemporary historiography of Dubai. Audio-visuals and dark stage-like spaces curate the visitor through a selected and sanitized 'past' of Dubai. All unsavory and potentially uncomfortable activities typical of a $19^{\text {th }}$-century port city have been excluded and replaced by vividly dressed girls costumed in local hairstyles and jewelry, reciting the Quran. Period rooms display small traditional shops laden with merchandise from the 1970's, pearl divers, and a desert section complete with falcons, camels, goats, Bedouins and traditional water canals (falaj).

Ethnographic sections in the museum have been intentionally darkened to merge the identity of real nationals among the visitors, most of whom still dress according to tradition, with the mannequins dressed as in the past, effectively constructing a powerful implied narrative - at once real and unreal - highlighting continuity and homogeneity. Additional elements, such as carefully selected short films and musical recordings, further enhance this experience. The effect of all this orchestration and editing is to naturalize a very specific cultural identity.

The Dubai Heritage Village reinstates this same pattern of sanitization, exclusion and artificiality, although it is perhaps even more selective in what it seeks to highlight. The village is divided into two principal sections, one part explaining aspects of Dubai's maritime past, including its pearl diving traditions. Here, a sense of living history is suggested by the inclusion of several local varieties of live fish in water basins. The other major part of the Heritage Village displays potters and weavers at work. The overall impression is that of the traditional non-urban life that existed in Dubai in the pre-petroleum era. Cultural re-enactments coupled with an architectural surround comprising construction with traditional materials lend an air of authenticity to the village and its contents. Men dressed as Bedouins sit on the sand next to various types of tents and stone huts and serve Arabian coffee. Women dressed in traditional clothing and leather facemasks cook simple variations of local foods. Dubai's Heritage Village participates in the wider practice of reconceiving historic buildings as venues for the experience of 'living' history. The highlight of this heritage village, as for others of the type, is the collection of buildings that serve to introduce aspects of local life and to support its interpretation through museological equipment, furnishings, and scripted activities conducted within the village (Young 2006).

Overall, like heritage villages elsewhere, the examples in Dubai are essentially populist recollections and re-tellings of history and local heritage in which the contingency and artificiality 
of the museological operation is subsumed under a form of theatricality, often unrecognized as such, which tends to pass for authenticity and in which personal interpretation of the sights presented is largely undisturbed by the curatorial apparatus of labels and narrative texts. Indeed, a personal and anecdotal voyeurism, which seeks quick visual access to the private reality of a past, provides a sort of 'viewer-glue' that holds together the illusion of 'reality witnessed'.

The classic museum and the heritage village are unsurprisingly the most visible museum types present in Dubai, just as these two types, and their corresponding emphases on in-context and insitu modes of object display, are obvious and dominant in the public museology present in many other cities around the world. In Dubai, however, history is re-produced and publically expressed in institutional types of additional kinds. Of special importance in Dubai are the theme malls, the most interesting examples of which are explicitly historical in nature; and the heritage house museums, which in their simplest form render the personal biographies and public achievements of important historical figures, or more generally important moments in history, through various forms of documentation displayed within the physical fabric of an historical house. In Dubai, these two museological types are evidenced most clearly in shopping centers such as the Ibn Battuta Mall, and in house museums such as the one housed in the Sheikh Saeed bin Maktoum residence, respectively.

\section{c) Theme Mall}

Theme malls such as the Ibn Battuta Mall, located on Sheikh Zayed road on the southwest margin of Dubai, and Khan Murjan, part of the Wafi City Mall in Oud Metha near the Dubai Creek, gather and reconstruct cultural backdrops similar to those constructed for the $19^{\text {th }}$-century World Fairs, albeit, in Dubai, in a very specific context of retailing and consumer spending. Such spaces of consumption and spectacle, which interweave shopping with a sense of history expressed in replicas, dioramas and text-heavy vitrine displays, should be understood as something like 'alternative museums'. As an historico-museological type, these malls have as much in common with the classic museum and the heritage village as each of these has with the other. Even the differences - and there are certainly many - are no more fundamental than can be seen between the museum and the heritage village. The theme malls perform historiographical interpretation, incorporate object/replica display, and include immersive experiences of history similar to the operations of the classic museum and the heritage village. They further perform these functions in largely inclusive and non-threatening ways, which helps explain their popularity as informal history venues. It would certainly be a mistake to imagine that these places perform purely mercantile functions; like the more familiar museum types, they also make genuine contributions to public knowledge. In these malls there is often as much activity centered on the historical displays as there is on the commercial exhibits arranged behind the nearby shop windows. Organized tours of school children and tourists routinely visit both the Ibn Battuta Mall and the Khan Murjan section of Wafi City Mall to get a sense of history portrayed there, and to do so in an environment with none of the pretension or pedantic rigor many visitors detect in other museum types.

Both the Khan Murjan and the Ibn Battuta Mall are arranged as spatial progressions through variously re-presented oriental environments. In Ibn Battuta, the sequence begins with facades representing North African architecture, then moves through spaces replicating Ancient Egyptian temples, Mamluk buildings, a Mughal court, under a grand Safavid/Persian dome, Timurid tiling, and finally ends with a full scale Chinese trading ship and Chinese temple. In putting into co- 
presence a vast range of cultures, times and epochs, the Ibn Battuta mall effectively captures a sense of the multi-ethnic mix out of which Emirati culture has emerged, and further mirrors the more recent evolution of Dubai as a multi-cultural and religiously diverse city. This correspondence between the assembled historico-architectural expressions constituting the mall's various courts and pathways, on the one hand, and the multiform population of Dubai, on the other, no doubt further helps to account for the mall's popularity. A shared sense of diaspora and mobility is reinforced by the mall's central and linking theme - the historiography of the $13^{\text {th }}$ century Maghrebi traveler Ibn Battuta, whose discoveries and adventures across a large part of the Arab world, and beyond, are documented in familiarly museological ways. The life of this tireless explorer is described, illustrated and explained through screens delivering texts next to replicated arts and artifacts related to his travels. Audio and interactive media combined with signs and displays illustrate arts and craft techniques typical of those encountered by the explorer on his journeys.

Overall, the mall effects a warm and comfortable environment where interior and exterior spaces are inverted, and where architectural contexts, replicated artifacts and entertaining explanations express selected features of remote cultures and histories. Theme malls like Ibn Battuta are open and accessible - to minority communities, accidental tourists, and recreational shoppers alike and end up delivering a museological experience that differs from those of the classic museum and the heritage village largely by degrees and variations, rather than by fundamental qualities (Figure 1). We will return to this point later, but is perhaps enough to note here that, as the blockbuster show phenomenon makes obvious, the museological enterprise is never entirely free of investments in public entertainment as accompaniment to its stated commitments to conservation, research and education, and, as any genealogy beginning with the 'cabinet of curiosities' should suggest, was perhaps never free of such investments.

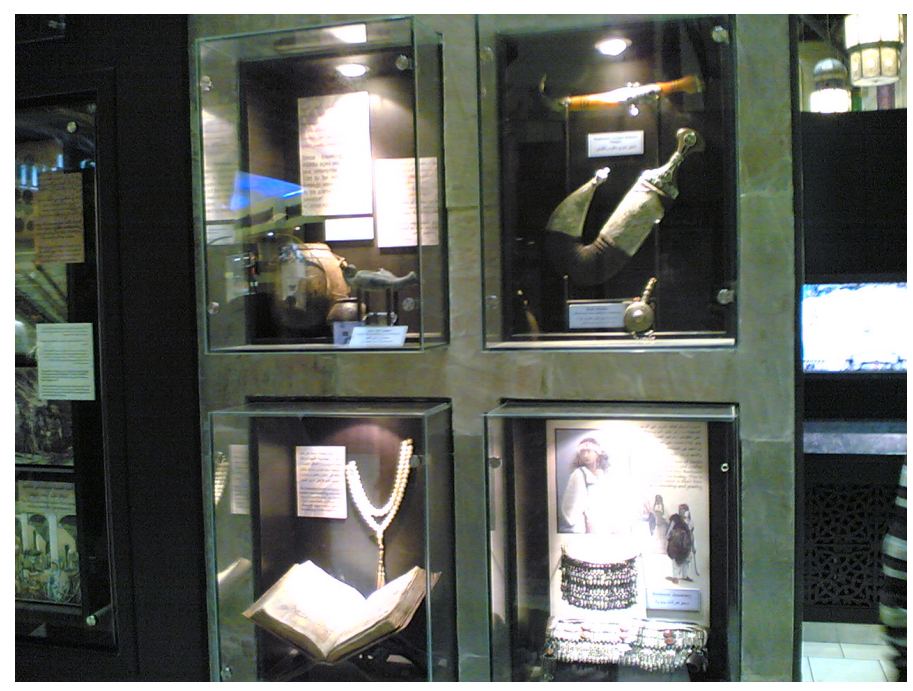

Figure 1. Museum-like display, Ibn Battuta Mall (author).

\section{d) House Museum}


An example of the final category of museum institutions in Dubai, the 'house museum', is the former residence of Sheikh Saeed bin Maktoum. The house is located near the mouth of Dubai Creek in al-Shindagha, one of the oldest areas of Dubai. The ruler of Dubai from just before the First World War until the late 1950s, Sheikh Saeed remains a widely appreciated figure in the history of the city. Accordingly, this museum has perhaps the highest public visibility of the various museums occupying historical residences in Dubai. The museum is comprised of one of many restored historical mansions in Dubai that have been reconstructed and fitted out in order to relate something of the lives and living conditions of their early owners and occupants, typically wealthy merchants or important political figures from Dubai's past. The Sheikh Saeed bin Maktoum museum attempts to offer a simple reflection of an important ruler's life through a standard collection of coins, stamps and old documents. At first sight, this seems little different from the collection of historical artifacts typically displayed in any in-context type museological effort. What is most interesting about museums like this, however, is the degree to which the artifacts presented are largely gratuitous, in the sense that they have no fundamental or intrinsic relationship to the ostensible 'object' of the museum - in this case, emphatically a personal or public 'life' at once absent in its physicality and only weakly 'reproduced' in the collection of photographs that dominate the display space. Indeed, the museum utilizes the generic collection of coins, stamps and other physical artifacts essentially to 'situate' the museum in a place and a time rather than to reflect or render the life of Sheikh Saeed. Many of the documents and photographs, on the other hand, do indeed relate directly to Sheikh Saeed's life, but they do so necessarily only as portrayals, renderings or secondary representations of that life, and even then largely as documentary records of a public role. Little of the intimate and detailed lived reality of the man himself remain here.

Another significant example of the house museum is the mansion of Obaid and Jumaa bin Thani, built early in the twentieth century and located near the Sheikh Saeed house in al-Shindagha. Now the Al-Siraaj gallery, this institution focuses on the history and meaning of Islam, relying almost entirely on representations and events rather than physical artifacts. In this, the institution very much emphasizes the theatrical and informational side of the museum as a type. Visitors approach the house from a busy thoroughfare and are taken through a series of rooms that form what is essentially a pilgrimage route opening with what are presented as the scientific miracles of the Quran, and then moving through illustrations of the creation of the universe and on to the various messages and messengers of Islam. The narrative is supported by very large scale graphics and information brochures, as well as by seminars delivered on a temporary stage in the center of the courtyard.

At the same time as a general history of Islam is presented, any sense of local Islamic tradition is bracketed, as is any trace of the circumstances or contexts at play in the construction or occupancy of the house or the role of the occupants of this and other heritage houses in the collective religious life of the community. The curators present their vision of an Arabian culture and a monolithic Islam and that surely never existed in anything like the pure forms suggested here. In a multi-ethnic port city, which has relied for centuries on the practical accommodation of multiple cultures and various religious traditions for its commercial survival, no such purity was possible.

Effectively, the house as a meaningful historical object is largely displaced as the building becomes a center of religious dissemination. Not only are specific references to local culture 
suppressed, but all traces of a life, a family, a social reality, the vicissitudes of economic fortune, the drama of political intrigue and the simple evidence of an everyday use of space, which together underwrite the practical meaning and historical importance of such a house, are systematically erased. Exhibition media and room size images crowd out any sense of collective memory that might be triggered by less intrusive insertions.

The displays obscure the intrinsic architectural character and historical functions of the house as home of Obaid and Jumaa bin Thani. Built in 1917, the house is historically important as one of the first residences in Al Shindagha district, an old historic neighborhood near the Dubai Creek, to reflect the prosperity of the area at a time when the local pearl trade was flourishing. Local people, their shops, crafts, customs and the commercial activities of the bazaar nearby are all part of a site context that remains crucial to understanding the meaning of the house, both now and in the past. In the current incarnation of the house as a scaffold for a general history of Islam, the site context serves as little more than a resource for funnelling visitors through the front doors. Effectively, Al-Siraaj gallery utilizes the physical integration of the house with its context to support visitor traffic, but effectively refuses any recognition that the physical setting of the object is part of what gives it both historical and contemporary meaning.

Overall, this is perhaps even more thorough a loss of original historical traces than is seen in the Sheikh Saeed bin Maktoum house museum. Both houses remain physically integrated into the urban fabric that surrounds them, but both also rely heavily on simulation strategies at once pictorial and theatrical. In other museum types, suppression of the physical building's history might be understandable or appropriate. However, suppression of the history of the Sheikh Saeed and Bin Thani houses - as distinct from the history documented, presented, or expressed as their respective 'contents' - is disconcerting in the context of a museum type, the house museum, that explicitly owes a debt of legitimacy to a structure and occupancy that lend it an air of historical rootedness not available to other museums types. That these houses are physically embedded in some of the last fragments of historical urban fabric in the city makes this erasure all the more troubling.

While the Sheikh Saeed bin Maktoum house and the house of Obaid and Jumaa bin Thani are perhaps the most important of the Dubai house museums, their constitution as museums shares much in common with other examples of the type. Related strategies are present in fortified residences such as Al-Fahidi Fort, now part of the Dubai National Museum complex, and in a number of historical mansions in the Dubai Creek area that have recently been converted into local museums and galleries. Although there is no space here to develop a full analysis of these examples, it is perhaps enough to note that all tend to privilege physical embedment into local sites while suppressing much of the meaning the building itself and its local context provide. At the same time, they tend to make extensive use of replicas and simulations in the absence of the historical objects with which they are concerned.

In the end, the Sheikh Saeed museum and other similar heritage house museums in Dubai are something like haunted houses - frozen in place, embedded in rapidly changing contexts, and filled with substitutes and weak replacements for the lives and events they attempt to animate and to which in various ways they owe their existence. The Dubai heritage house museums, in fact register in spatio-museological form precisely the core condition of all biography and much history - the definitive loss of important objects of commemoration. In many such cases, these are not artifacts at all, but lives, contexts and meanings now utterly and irretrievably gone. This is 
a point to which we will return later, but even here it is clear that the house museum and their 'lost objects' are only extreme examples of the inevitability of selective loss that haunts all museum types and their various museological strategies.

\section{THEORETICAL OBSERVATIONS}

In the theme mall and the house museum, then, meaning is produced largely in the absence of the historical artifact. This is obviously the opposite of the situation evidenced in examples of in-situ and in-context types, predicated, as they are, upon a logic (if not always the fact) of object presence. At the same time, however, both the theme mall and the house museum are thematically related to the classic museum and the heritage village, although here as much in contradiction as in correspondence. A powerful concept for mapping sets of terms with similar relationships is the semiotic square, particularly in the form most closely associated with Fredric Jameson. Unlike the early innovators of classic formulation of the semiotic square, who assumed the tool mapped out and exhausted the range of strict logical possibility (Greimas 1987), Jameson's great insight was to understand that the semiotic square could be used to map what he called 'ideological closure' - essentially what remained generally 'thinkable' at any historical moment, rather than what might be strictly possible to imagine (Jameson 1987). As museology is, among other things, a thought-construct, we may benefit from putting the semiotic square to use in mapping the various historico-museological types evident in Dubai.

To this end, we can position in-situ and in-context approaches as an initial pair forming two legs of a semiotic rectangle centered on object presence, in which the meaning of the object is assumed to be provided by curatorial interpretation, on the one hand, and integration into the object's proper physical environment, on the other. This is, after all, the pairing that KirshenblattGimblett rightly identifies as fundamental to the museum enterprise. We could label the three corners so produced as object, interpretation and integration. The square can then be completed with a term that recognizes the importance of object absence in the theme mall and the house museum. In fact, what characterizes object absence in the theme mall and the house museum is a 'filling' of that absence with representations and copies of various kinds, as we have already seen. For simplicity, we can label these broadly as simulations. This allows our rectangle to be completed as follows (Figure 2). 


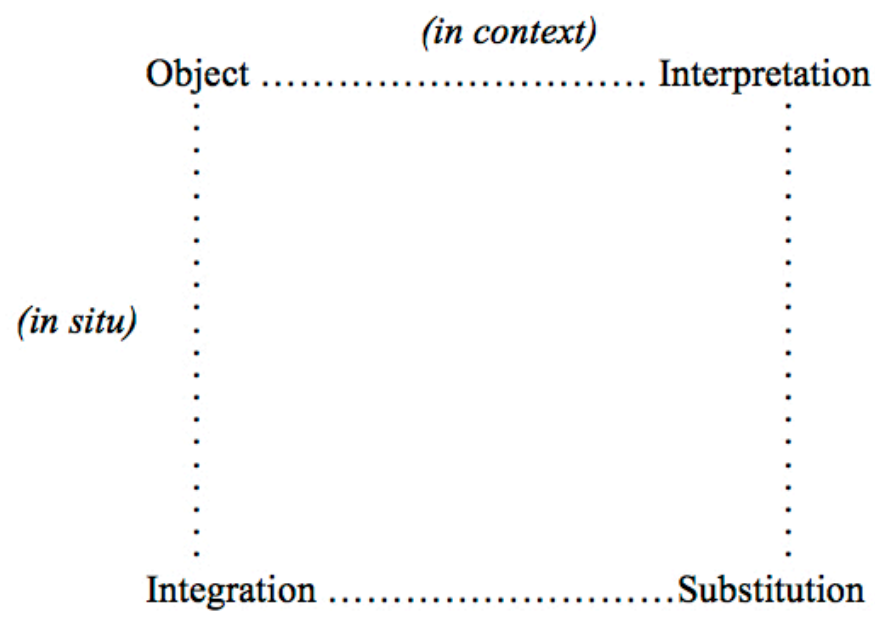

Figure 2. Basic semiotic square: object, interpretation and integration, simulation.

This four-square structure of basic terms allows us to place the museum types we have discussed to this point, as regards Dubai, into the four primary positions of what is usually called the 'expanded field'. In other words, this structure allows us to position both artifact-oriented and representation-oriented historico-museological types into a single structure, and further allows us to map in schematic form the four primary institutional vehicles for the public transmission of history in Dubai. Filling in the expanded field terms results in the following diagram (Figure 3).

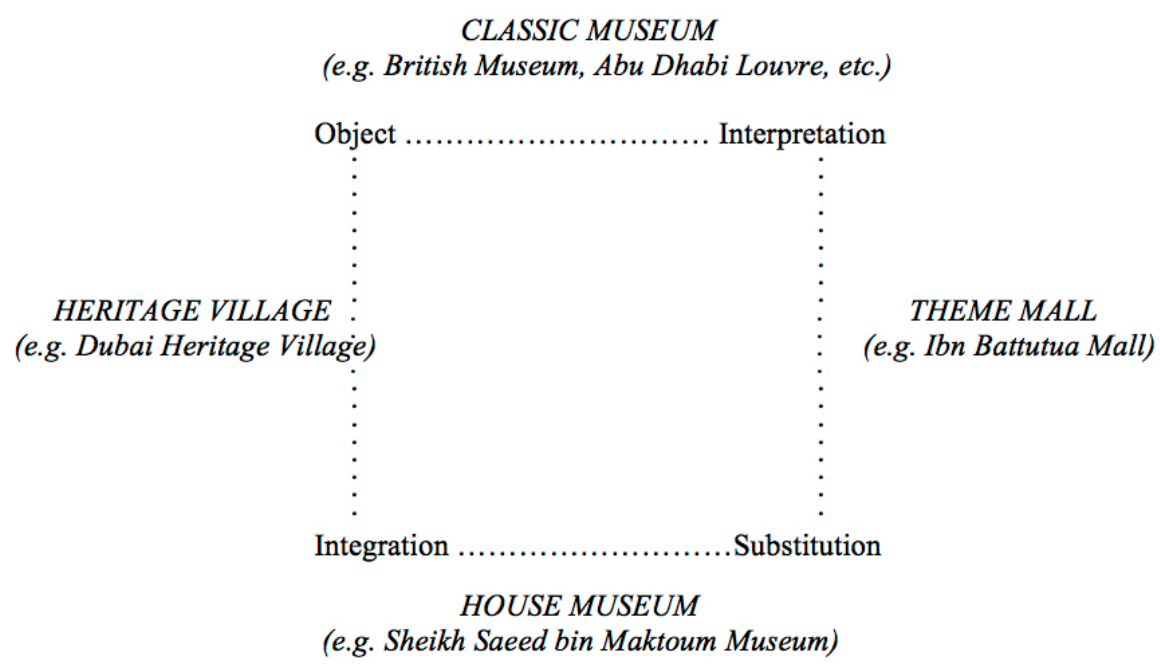

Figure 3. Expanded field: classic museum, heritage village, theme mall, house museum. 
Without making any claims for the wider applicability of this mapping beyond Dubai, the viability of this semiotic structure is reinforced by expansion of the inner field to include the possibility of two new pairs in combination: artifact presence (object) with object absence (simulation), on one cross axis; and discursive positioning (interpretation) with environmental embedment (integration), on the other - two sets of terms neither directly expressed in Kirshenblatt-Gimblett's in-situ/in-context model nor possible to accommodate in a strictly conceived semiotic rectangle of logical oppositions and contradictions. These cross-axes represent an orientation to the object, in the first case, and to historical meaning, in the second. Upon reflection, it is clear that these inner field expansions effectively map, respectively, the enterprise of artifact restoration (in which elements of authenticity and simulation coexist in a single artifact), and the historical marker (in which an authentic site and interpretive statement are brought together in the absence of an original artifact). These six expansions together map out a plausible set of operative categories deriving from an initial supposition of artifact centrality as proposed in Kirshenblatt-Gimblett's 'Objects of Ethnography' essay, and further developed in the context of Dubai's specific institutional typologies.

\section{CONCLUSIONS}

At the outset, we noted that we would see that the network of Dubai's museums and museum-like institutions constitute an essentially symbolic resolution of an oddly inconsistent condition: in a context characterized by irretrievable historical loss, a sense of historical continuity and completeness is everywhere. That such a loss is keenly felt in Dubai, and in the Emirates more generally, is amply evidenced by the angst and anxiety popularly expressed in the press, on the street, and in policy circles in regards to increasing lack of proficiency in Arabic language, particularly local varieties, the rapid disappearance of inherited patterns of life and social relationships in favor of 'imported' models, and an apparent lack of appreciation for and interest in local cultural knowledge among younger generations. Along with this felt sense of loss, however, we also see everywhere in the city expressions of fullness and continuity, much of it relying on various appropriations and renderings of history.

We are now in a position to see more clearly how this is true and what its implications may be. It is clear that the four fundamental museum-like institutions we have studied through examples in Dubai (classic museum, heritage village, theme mall, house museum) can be placed in a logically consistent conceptual structure expressible in the form of a semiotic square. It is also clear that each institutional type can be characterized in terms of the dominance of a pair of two more basic terms (object, simulation, integration, interpretation). If it has been plausible for us to claim, following Jameson, that a form of ideological closure is manifest in the system of museum-like institutions in Dubai, it remains to be seen what this system can tell us about Dubai.

Certainly, the theme malls in Dubai reflect the sense of a city with an ongoing obsession with spectacle and commodification, just as the presence of Dubai's house museums at one level reflect a wider tendency toward hagiography and rhetorical support for the legitimacy of historical rulers and their present inheritors. Combined with the fundamental historiographical condition of selective loss and the impossibility of any certain recoverability of the past, this has 
resulted in a structural situation characterized by a loss of objects, events and meanings that is at once historically inevitable and politically willful.

But just as historical loss is selective, so is the 're-membering' of history that Preziosi speaks about, especially the very particular ways that both knowledge and citizens themselves are 'fabricated' by the museum (Preziosi 2004). Particularly at a time of regional political instability and very real threats to standing political regimes, the various ideological orientations of the house museums are easily understood. At the same time, a receptive public's understandable desire for reassurance in the face of rapidly disappearing cultural and linguistic heritages, and a religious tradition under increasing strain, coupled with a countervailing desire for distraction and entertainment, explain the popularity and impact of Dubai's theme malls. In the system of museum types evident in Dubai, these various strands of forgetfulness find themselves at once expressed in, and rhetorically overcome - as symbolic resolutions of this entirely extrainstitutional set of conditions in Dubai and its region - in a fullness of re-membering that passes for authentic preservation of knowledge and meaningful understanding. Above all else, the semiotic square of Dubai's museum types expresses in simple diagrammatic form this basic condition: apparent conceptual completeness and epistemological closure of a set of presented 'histories' that are anything but neutral or complete.

Before we judge Dubai's institutional museology too harshly, dismissing what we have seen here as a locally acute expression of historical distortion, however, we might stop to consider just how much there is in common here with all modern historiography. Dubai's museums types help illuminate the specific conditions and forces present in Dubai, but they also capture something more fundamental - the artificiality of the mall and the partiality of the house museum signal the historical uncertainty otherwise suppressed in the object-driven in-situ and in-context approaches where the supplements of physical embedment or interpretive explanation tend to erase doubts about validity and meaning. Museums always tell particular stories, but when we are offered stories largely without the centrality of the objects that ground them, the museological enterprise becomes startling clear: it is always comprised of loss and forgetfulness, and always tends toward completeness and recollection. What the Dubai case further forcibly reminds us is that even under selective loss and rhetorical closure, and perhaps especially then, there is always the possibility of re-membering otherwise. Just as a simple conceptual mapping can begin to bring to light otherwise faint or unremarked assumptions and preconditions, that same exposure opens onto unnoticed possibilities and alternatives.

\section{References}

Acuto, Michele. 2010. "High-rise Dubai: urban entrepreneurialism and the technology of symbolic power". Cities 27 (4): pp. 272-284.

Anderson, Gail. 2004. "Introduction: Reinventing the museum". Pp. 1-7 in Reinventing the museum: historical and contemporary perspectives on the paradigm shift. Oxford: AltaMira Press.

Bagaeen, Samer. 2007. "Brand Dubai: The Instant City; or the Instantly Recognizable City". International Planning Studies 12 (2): 173-197. 
Baxandall. Michael. 1991. "Exhibiting intention: some preconditions of the visual display of culturally purposeful objects". Pp. 33-41 in Exhibiting Cultures: the Poetics and Politics of Museum Display, eds. Steven Lavine and Ivan Karp. Washington: Smithsonian Institution Press.

Coombes, Annie. 1988. "Museums and the Formation of National and Cultural". Oxford Art Journal 11 (2): 57-68.

Davis, Mike. 2007. "Sand, Fear and Money in Dubai", Pp. 48-68 in eds. Mike Davis and Daniel Monk Evil paradises: Dreamworlds of neoliberalism. New York: New Press.

Greimas, Algirdas Julien. 1987. On Meaning: Selected Writings in Semiotic Theory. Trans. and Eds. Paul Perrin and Frank Collins. Minneapolis: University of Minnesota Press.

Hooper-Greenhill, Eilean. 2000. "Changing Values in the Art Museum: rethinking communication and learning.” International Journal of Heritage Studies 6 (1): 9-31.

Jameson, Fredric. 1987. "Forward." Pp. vi-xxxii in Greimas, Algirdas Julien. On Meaning: Selected Writings in Semiotic Theory. Trans. and Eds. Paul Perrin and Frank Collins. Minneapolis: University of Minnesota Press.

Kanna, Ahmed. 2005. “The 'State Philosophical', in the 'Land without Philosophy': Shopping Malls, Interior Cities, and the Image of Utopia in Dubai", Traditional Dwellings and Settlements Review, 16 (2): 59-73.

Kaufmann, Edward. 2004. "The Architectural Museum from World's Fair to Restoration Village.” pp. 273-289 in Museum Studies: An Anthology of Contexts, ed. Bettina Carbonell. Oxford: Blackwell.

Kirshenblatt-Gimblett, Barbara. 1991. "Objects of ethnography.” Pp. 386-443 in Exhibiting Cultures: the Poetics and Politics of Museum Display, eds. Steven Lavine and Ivan Karp. Washington: Smithsonian Institution Press.

Preziosi, Donald. 2004. "Brain of the Earth's Body, Museums and the Framing of Modernity." Pp. 71-84 in Museum Studies: An Anthology of Contexts, ed. Bettina Carbonell. Oxford: Blackwell.

Shaw, Wendy. 2003. Possessors and Possessed: Museums, Archaeology, and the Visualization of History in the Late Ottoman Empire. Berkeley: University of California Press.

Smith, Benjamin. 2010. "Scared by, of, in, and for Dubai." Social and Cultural Geography 11 (3): 263-283.

Spalding, Julian. 2006. “Dead Circuses.” History Workshop Journal 62 (1): 318-325.

Steiner, Christian. 2010. "From heritage to hyper-reality? Tourism destination development in the Middle East between Petra and the Palm." Journal of Tourism and Cultural Change 8 (4): 240253. 
Watenpaugh, Heghnar. 2004. "Museums and the Construction of National History in Syria and Lebanon." Pp. 185-202 in The British and French Mandates in Comparative Perspective, ed. Nadine Méouchy and Peter Sluglett. Leiden: Brill.

Young, Linda. 2006. "Villages that Never Were: The Museum, Village as a Heritage Genre". International Journal of Heritage Studies 12 (4): 321-338 